\title{
S-nitroso- $\mathbf{N}$-acetylcysteine attenuates liver fibrosis in experimental nonalcoholic steatohepatitis [Corrigendum]
}

\author{
Mazo DF, de Oliveira MG, Pereira IV, Cogliati B, Stefano JT, \\ de Souza GF, Rabelo F, Lima FR, Ferreira Alves VA, Carrilho FJ, \\ de Oliveira CP. Drug Des Devel Ther. 2013:7:553-563.
}

On page 554, the sentence "Therefore, we chose SNAC as a potential antifibrinogenic NO donor drug for treating fibrosis..." contains an error. The term "antifibrinogenic" should be replaced by "antifibrogenic".

On page 558, Figure 3 (D), the intermediate block corresponding to SNAC is missing. The correct figure is shown below.
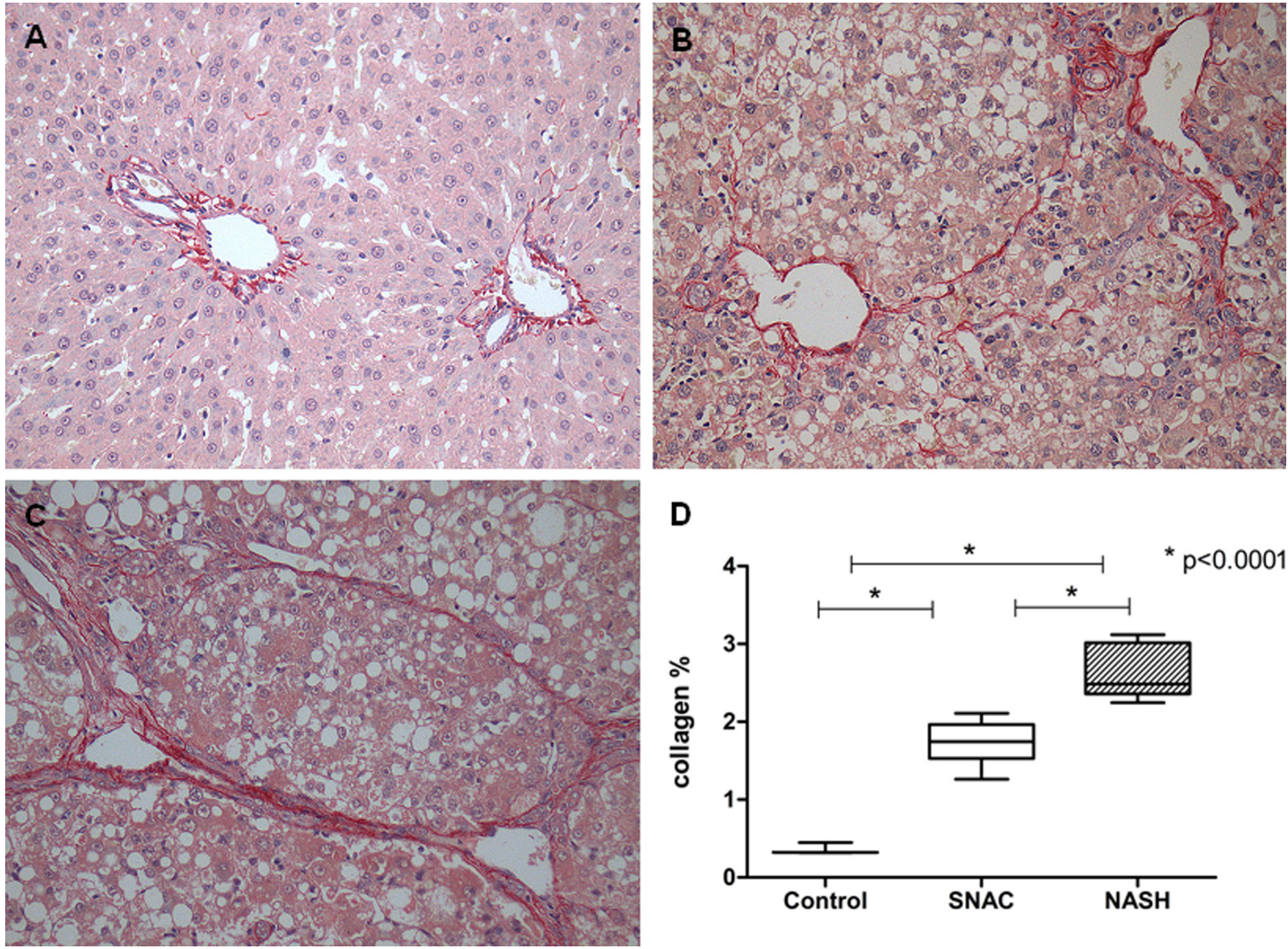

\section{D}

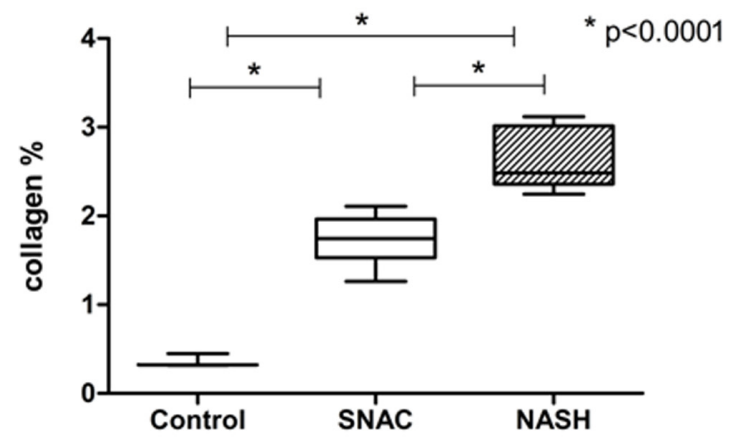

Figure 3 Representative picrosirius red staining images of hepatic histology of (A) control, (B) nonalcoholic steatohepatitis (NASH), and (C) S-nitroso-N-acetylcysteine $($ SNAC) treated animals. Magnification is $\times 200$. (D) Collagen quantification of the control, SNAC, and NASH groups.

submit your manuscript $\mid$ www.dovepress.com

Dovepress

http://dx.doi.org/10.2147/DDDT.S52000 


\section{Publish your work in this journal}

Drug Design, Development and Therapy is an international, peerreviewed open-access journal that spans the spectrum of drug design and development through to clinical applications. Clinical outcomes, patient safety, and programs for the development and effective, safe, and sustained use of medicines are a feature of the journal, which has also been accepted for indexing on PubMed Central. The manuscript management system is completely online and includes a very quick and fair peer-review system, which is all easy to use. Visit http://www.dovepress.com/testimonials.php to read real quotes from published authors.

Submit your manuscript here: http://www.dovepress.com/drug-design-development-and-therapy-journal 